\title{
Materials and sustainable development
}

\author{
F. El-Hajjaji ${ }^{1}$ M. Abdel-Daim² ${ }^{2}$ B. Hammouti ${ }^{3}$ M. Taleb ${ }^{1}$ \\ Published online: 2 December 2021 \\ This is a U.S. government work and not under copyright protection in the U.S.; foreign copyright protection may apply 2021
}

This editorial introduces to a Special Issue of Environmental Science and Pollution Research, highlighting selected papers presented at the international symposium on "The Fourth International Conference on Materials and Environmental Science (ICMES2020)", is organized by Mohammed Premier University, Faculty of Science, Oujda Morocco, and the Association: Moroccan Center for Sciences DevelopmentMOCEDES. The purpose of the symposium was t o present an interdisciplinary platform for researchers and industrials to promote a multi-sectoral and collaborative approach in the field of development of new and innovative approaches in materials and their applications in energy and renewable energy, environmental science and sustainable development, and biotechnology and electrical engineering.

In detail, more than a dozen papers on processes and environmental quality in the materials and sustainable development are presented in this special issue elucidating the following topics:

- Organic, inorganic and nanomaterials

- From natural products to their biotechnological applications

- Quality, water, environment, health and safety at work

- Renewable energies and sustainable development

- Electrical engineering and physics simulations

- Materials physics and chemistry

- Soil and water management techniques in agriculture

- Emerging materials for energy storage

Responsible Editor: Philippe Garrigues

Prof. Dr. F. El-Hajjaji

el.hajjajifadoua25@gmail.com

1 Engineering Laboratory of Organometallic, Molecular Materials, and Environment, Faculty of Science, USMBA, Fez, Morocco

2 Department of Zoology, Science College, King Saud University, Riyadh, Saudi Arabia

3 Faculty of Sciences, First Mohamed University, Oujda, Morocco
- Materials and devices

- Advanced energy materials

The main objective is to bring together leading academic scientists, researchers, and industrials from Africa, North and South America, Europe, Asia, Australia, and Middle East to exchange and share their experiences and results related to material and environmental science. ICMES is providing an interdisciplinary platform for researchers and industrials all over the world with complementary, strong, and diverse expertise. The participants will have the opportunity to discuss the most recent innovations as well as to initiate possible complementary cooperation and collaboration through international programs by creating a direct contact between international experts. The goal here is also to promote exchange of Master, PhD students, and Post-docs between the different academic partners.

In detail, 8 communications on material and environmental science:

- Influence of the effect of nanoparticle additives blended with mahua methyl ester on performance, combustion and emission characteristics of CRDI diesel engine

- COVID-19: unbalanced management of occupational risks case of the analysis of the chemical risk related to the use of disinfectants in the dairy industry in Morocco.

- Modeling and numerical simulation of the chip formation process when machining Nomex

- Effect of n-amyl alcohol/biodiesel blended nano additives on the performance, combustion and emission characteristics of CRDI diesel engine

- An experimental assessment on the influence of high fuel injection pressure with ternary fuel (diesel-mahua methyl ester-pentanol) on performance, combustion and emission characteristics of common rail direct injection diesel engine

- Reuse of treated wastewater and non-potable groundwater in the manufacture of concrete: major challenge of environmental preservation 
- Temperature and extraction methods effects on yields, fatty acids and tocopherols of prickly pear (OPUNTIA FICUSEEINDICA $\hat{E} L$.) seed oil of eastern region of Morocco

- Ethnobotanical survey about medicinal plants used in traditional treatment of insomnia, asthenia and oral and gum infections in the region Fez-Meknes, Morocco

Publisher's Note Springer Nature remains neutral with regard to jurisdictional claims in published maps and institutional affiliations.

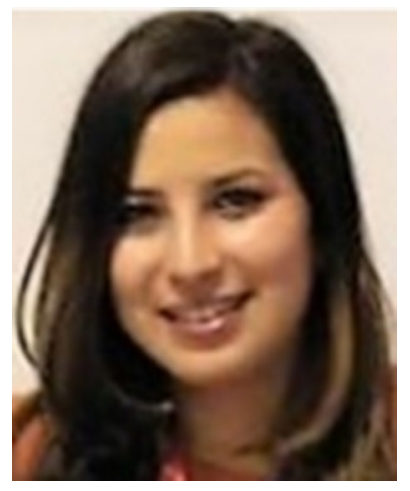

Professor. Dr. El Hajjaji Fadoua She received her Phd in physical chemistry and exactly in materials and corrosion science, from USMBA, Fez, Morocco, in 2015. She is currently a Professor in Chemistry Department, the Faculty of Science, University Sidi Med Ben Abdallah, Fes, Morocco. Her research interest covers corrosion inhibition By synthesized compounds as well as natural compounds. The main objective is to improve the resistance of materials in an acidic medium by adding inhibitors.

She started by studying the structure of molecules; she has published more than 75 papers in international journals indexed; these works have been presented in national and international scientific events in the form of 200 communications oral and poster. She is an organizing and scientific member of several national and international events. She was invited to review many papers in international journals; she is also an editor assistant of JASES resident in USMBA. Laboratory of Engineering, Organometallic, Molecular and Environment (LIMMOME), Faculty of Sciences, University Sidi Mohamed Ben Abdellah, Fez, Morocco. e-mail: el.hajjajifadoua25@gmail.com

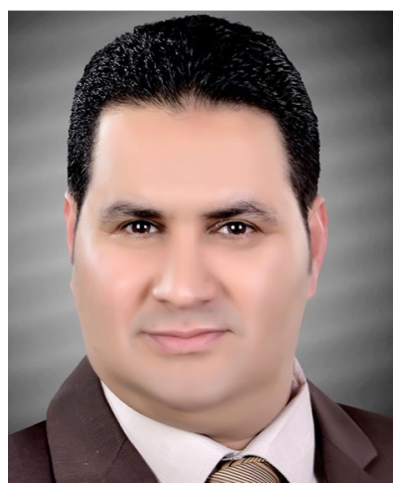

Prof.Dr. Mohamed Abdel-Daim He is an associate professor of Pharmacology, Faculty of Veterinary Medicine, Suez Canal University, Ismailia, Egypt. He was published many manuscripts in experimental and food animals at many scientific journals related to Pharmacology, Drug Toxicology, Biochemistry, Clinical pathology and Molecular Biology. He is currently a member of Research Ethics Council, Academy of Scientific Research \& Technology, Egypt. He has high experience in revision activities in more than 140 scientific journals. His research interest covers Pharmacology, Toxicology, Alternative Medicine, Drug Toxicology, Analgesic, Anti-inflammatory, Anticancer, and Antioxidant.

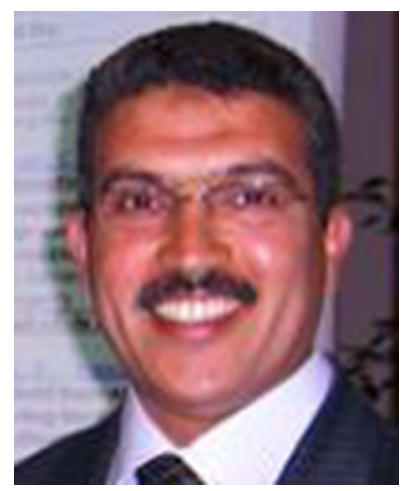

Prof. Dr. Belkheir HAMMOUTI Prof. Dr. B. Hammouti was awarded a $\mathrm{PhD}$ degree in corrosion science in 1994. He is currently a Professor in the Faculty of Science, University of Mohammed I, Oujda, Morocco. His research interest covers acidity sensors and corrosion inhibition of iron, steel, lead, Aluminium and copper in mineral acids by Tetrazole, Pyrazole, Polymer, Thiophene, Pyridine, Peptide, Aminoacid and Ester compounds. He has published more than 700 papers in corrosion and sensors fields. In March 2006, he received the Elsevier Award as the most published author in Morocco since the year 2000. On July 30, 2015 on the occasion of the 16th anniversary of King Mohamed VI's accession to the throne day, Prof. Hammouti decorated of Wissam (Faress) by His Majesty The King of Morocco Mohammed VI.

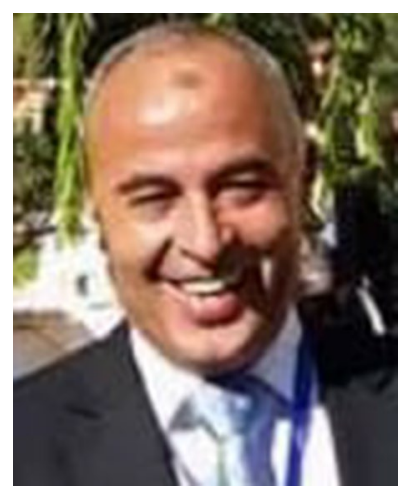

Prof. Dr. Mustapha TALEB he hold a Ph.D. degree in Electrochemistry from the University of Mohammed Premier-Oujda, Morocco, his research interest covers corrosion inhibition by syn1thesized compounds as well as natural compounds. He has published more than 110 papers in international journals and he presented about 500 communications and some conferences. He is a reviewer at several international journals, he is also an editor of JASES resident in USMBA. 